\title{
PROGRESSIVE AND DEVELOPMENTAL PATHWAYS FOR STUDENT RETENTION AND ACADEMIC SUCCESS: LESSONS FROM ONE-ON- ONE STUDENT ACADEMIC ADVISING
}

\author{
R. Emekako* \\ Directorate for Faculty Teaching and Learning Support, \\ Centre for Teaching and Learning and Edu-Lead Research Entity \\ https://orcid.org/0000-0002-1236-6662
}

\section{S. van der Westhuizen*}

Directorate for Faculty Teaching and Learning Support, Centre for Teaching and Learning https://orcid.org/0000-0001-6862-9620

*North West University

South Africa

\section{ABSTRACT}

Once higher education institutions grant access to students, it is only normal that these institutions provide continual support using appropriate frameworks which consider both academic- and social-related challenges students face. This practice-based study portrays the role played by the Centre for Teaching and Learning (CTL) at a traditional-based university in South Africa in the provision of excellent and innovative, research-informed guidance and support in teaching and learning to students in a contemporary higher education context. More specifically, the article was theorised from "intentional" academic advising (AA) as an approach that informs AA practices and thus leads to progressive academic improvement, retention and success of students through oneon-one AA consultations. Two sets of samples were used to account for the improvement of academic performance emanating from consultations. Anonymity and confidentiality were ensured to protect participating students' personal information. The findings revealed that, through the application of the "intentional" process (through the knowledge of theories on student development, experiences of advisers and student background), variable academic gain was reached in student advising. Although first-year students consulted more, most academic gain was experienced by exiting third-year students, particularly when they requested help on study methods in higher education. It is concluded that an enlarged and more comprehensive dataset (which includes across-campus data) and a qualitative pooling of the experience of academic advisers across campuses would allow for better understanding of the influence of AA practice on academic success. It is recommended that the "intentional" process be applied consciously and be used in professionalising advisers. Finally, it is also recommended that a study be conducted to look into the influence of all components of the support framework within the institution on a cohort depicting the diverse background of students enrolled in the institution. 
Keywords: academic advising, academic advisers, retention, academic success, higher education.

\section{INTRODUCTION}

Institutions of higher learning are tasked with using curricula and institutional policies and structures to progressively develop pathways to success for enrolled students (Council of Higher Education (CHE) 2013a). These functions are normally broadly embodied in the roles of teaching and professional support staff that operationalise institutional policies, structures and curricula according to their institutions' vision and mission statements. The main business of higher education institutions (HEIs) are teaching and learning, research, and community engagement. For students to succeed in their pursuit of academic excellence and knowledge acquisition and generation, it is important that HEIs design robust student support frameworks. According to Benedicks (2018), learning is an intrinsic human activity which needs to be nurtured and supported in many ways.

Taking cognisance of Tinto's revised model of student integration, student academic advisers understand that "[students'] goals and intentions are continuously reshaped through interactions within their institutions' academic and social structures" (Schreiber, LuescherMamashela, and Moja 2014, v). Thus, providing access without some form of support to students usually results in student failures and dropout (Tinto 2014). Support may be academic and social by nature. After students are admitted to an institution, their motivational level, choices, association, behaviours, orientation and the support experienced can largely determine their success within and outside their institutions of learning (Kimball and Campbell 2013; Pascarella and Terenzini 2005; Tinto 2014).

The Centre for Teaching and Learning (CTL) (at a traditional university in South Africa in the case of this article) houses professional staff who are tasked with providing excellent and innovative research-informed guidance and support in teaching and learning to lecturers and students within a contemporary and transformed higher education context. This article is situated in Student Academic Development and Support (SADS) services within CTL. The aim of SADS is to upskill students through ventures that can enhance academic achievement and overall success. More specifically, student academic advisers are responsible for developing students' reading techniques, critical thinking and problem-solving skills, note-taking techniques, time-management skills, learning and revision strategies, memory rehearsal skills, and test- and exam preparatory skills. Academic advising (AA) is just one of the support/retention frameworks employed by SADS at the case institution. Other frameworks are academic peer mentoring, learning management system (LMS) support, first-year experience, 
reading centre, supplemental instruction, tutoring, workshops, et cetera.

For student academic advisers to contribute to progressive and developmental pathways for student retention and academic success, this article espouses data of the support rendered by such advisers to undergraduate students at the case institution, providing a theoretical lens of "intentional" advising and how this is translated to the possible academic improvement of students who consulted with student academic advisers. The authors achieved this by manipulating the variables that influence student pathways to success (Drake 2011; Kimball and Campbell 2013). The independent variables (i.e., frequency of consultation, study level, referring entities, and student needs) were manipulated to investigate if academic improvement had been achieved. This article affirms that AA is not the only factor responsible for academic development of students. It only seeks to understand the level of possible impact of AA on the development of students' academic performance. The data show the importance of AA and the areas of student needs that should be focused on. Hence, AA is not a sole determiner of student retention but may contribute to improved performance.

\section{AIM OF THE STUDY}

The progressive and developmental pathways geared towards student retention are offered through the lens of one-on-one student AA, carried out over two consecutive academic years, at a traditional tertiary institution in South Africa. Students opt for one-on-one advising for different reasons, but all aimed at student academic development. The aims of this study were as follows:

- to present a literature review that captures the "intentional" process of AA which theoretically informs advisers on AA;

- to determine the influence of AA on academic performance using pre- and postexamination results after exposure to one-on-one consultation on a short-term basis.

One-on-one student AA is only one of many retention strategies in HEIs. The data from this study indicate what "good" advising could do and how this should be further strengthened on a long-term basis.

\section{LITERATURE}

\section{The importance of academic advising}

Academic advising ${ }^{1}$, as expressed by Drake (2011), goes beyond mere recordkeeping of student academic activities. It is centred on the human art, or ability of building relationships with 
students in a way that positively reveal the best personal, emotional and academic intentions of students to attain academic success and, subsequently, their life goals. Academic advising becomes one of the crucial tools useful to higher education stakeholders - such as faculty management, support centres of teaching and learning, and even professional bodies - to increase student retention and success.

To explain the value of AA, we draw on a story of a regular student named Bernie in Drake's article on the "role of academic advising in student retention and persistence" (Drake 2011, 8). Although Bernie never felt connected with the students in all his classes, he felt extremely comfortable with his co-workers from his regular summer job. He attributed "feeling out of place" to not being "vocal enough", which he unfortunately perceived as not being as "intellectual" as his peers. These feelings of inadequacy made Bernie consider dropping out of school. Bernie's inability to speak up in his classes prohibited his instructors to notice his intelligence, sensitivity and great wit. To prevent Bernie from dropping out, a student academic adviser was appointed to support him. Their interaction resulted in a strategy to empower Bernie to find the courage to participate in class and be heard by his fellow students and instructors. Bernie continued to graduate summa cum laude with a degree in English (Drake 2011).

Bernie's perseverance and ability to ultimately graduate as one of the top students is largely attributed to establishing a supportive relationship that contain components of mentoring, advising and communication. Through the interaction of a faculty member (the lecturer/instructor) and the student academic adviser, Bernie progressed to achieve his life goals. Bernie's experience emphasises the importance of student AA as an "intentional" process that progressively contributes to student retention and increased student academic development and success within an HEI.

In addition to the above, an example of such a relationship is also between a student academic adviser and a student at the case institution. During the consultation, it became clear that the socio-economic circumstances of the student had a profound influence on her academic performance. Before AA commenced, the student academic adviser first consulted with social services, campus medical services and student counselling services. The student could focus on her studies after her socio-economic issues were dealt with. She continued to show progressive academic excellence.

\section{The "intentional" process of academic advising}

Student academic advisers support students from diverse backgrounds. Different values and beliefs shape students' experiences before they gain access to university. To a considerable 
extent, success in AA depends on advisers' awareness of the theories of student development and experiences and their ability to employ multiple strategies. Thus, the "intentional" process of $\mathrm{AA}^{2}$ is informed critically through reflective practices of what might be considered as the breadth of scholarship and practice that shapes student experience, development and advising, which are values, beliefs and assumptions, theories, advising approaches and advising strategies of advising professional staff in an institution (Kimball and Campbell 2013).

Experiences shape the beliefs and value systems of students, academics and student academic advisers, which then determines their behaviour. Due to the unique belief systems of the different role players in advising, it is important for that student academic advisers be careful of the theoretical framework they use in guiding scholarly theories, advising strategies and approaches (Levin and He 2008). Therefore, what we say to and do with our students should be unique at all times when dealing with student AA.

Scholarly theories and advising strategies and approaches (Levin and He 2008) are expected to change practice by changing behaviour, which is often generalisable circumstances that have been tested over time and held true (or were at least accurate) to a group of communities (Jaccard and Jacoby 2010). AA as a practice does not profess theories, as it depends on various theoretical lenses from different disciplines, for example, anthropology, sociology, philosophy, et cetera. Furthermore, AA leans on research and scholarship production on student development and experience as well as student success. Some examples of studies from a theoretical perspective come from work on understanding student existence within a campus environment (Harper and Quaye 2009; Strange and Banning 2001) and on student developmental pathways (Evans et al. 2010). It is important that student academic advisers be conversant with literature on student wellbeing and development to enable them to provide students with good support, with considerations given to institutional support frameworks. From the above-mentioned, it is clear that student academic advisers' approach to the development of a student emanates from their philosophy, which is a combination of concept literature, theories and experiences. With respect to experiences, information gathered from regular conversations with colleagues and engaging with students affect advisors' approach. This implies that having a clear or an "intentional" approach is not always possible and that the desired outcomes are not always achievable. It is important, though, that student academic advisers consciously attempt to align their approach with students' beliefs and values for the sake of student academic development and support, since it is only by acknowledging our students as individuals that we truly respect diversity.

Ideally, strategies and approaches in AA can be viewed as two-sides of a coin - they must 
align. A strategy should consider an organisation's settings, which, in this case, is the university (Kimball and Campbell 2013). In the case university used for this study, students could walk in voluntary for student AA. Student academic advisers then proceeded to offer support directly and/or indirectly. Indirect support refers to further referral to other support frameworks offered within CTL, or other relevant institutional support services and resources.

What is clear is that no standard procedure applies in AA; rather, what matters is how each situation is treated uniquely. In South Africa, "just under half of the young people who enter undergraduate degrees (for either contact or distance mode) never graduate" (Department of Higher Education and Training [DHET] 2017, 20). Although not only AA is responsible for the failure rate, student academic advisers must be capable of creating meaning out of each student's situation: they should be able to understand the beliefs and value systems of the student before developing an approach and strategy based on experiences and applicable theories. It is important that advisers also understand the context of their institution in terms of student diversity. This helps to create a socially just, inclusive approach that is responsive to the needs of diverse learners when using institutional resources to develop pathways for the lifelong learning of students. Figure 1 illustrates the levels of knowledge of AA when developing “intentional” AA.

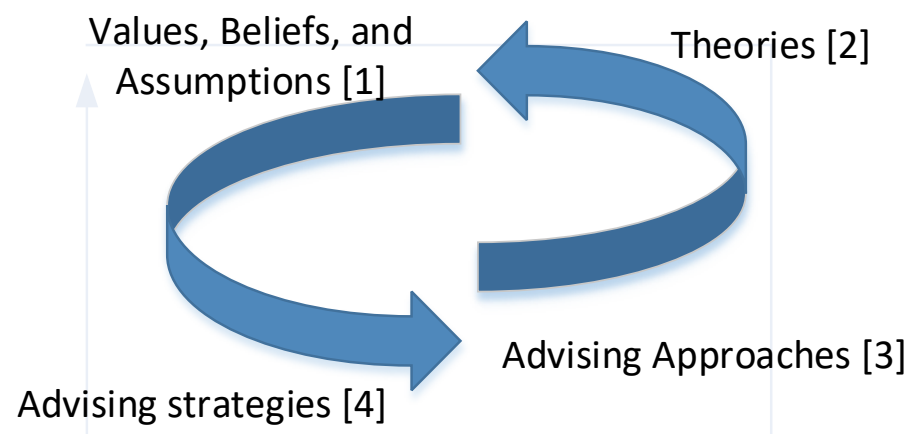

Figure 1: Levels of advising knowledge (Kimball and Campbell 2013)

The narrative thus far and this practice as depicted in the above figure confirm Hutson, Bloom, and He's (2009) call for reflective advising so student academic advisers move on a continuum to design the best plan of action for students' development. In numerical order, the levels suggest that the values, beliefs (and implicit biases) and assumptions of the student academic adviser and student determine the theoretical frameworks/foundations upon which an approach is developed and then the affordances of the institutional strategy. Since practice is often somewhat shaped by experiences as theory is consumed, the success of this model should be revised/revisited/observed to include a reiterative process and be changed regularly for the 
overall development of the student.

\section{Advising for the success and development of students}

This section shifts from "what" and "how" advising should be conducted to its impact and outcome. The goal of AA is achieved when the success and development of students are observed or measured, especially within an academic institution.

This section draws from and offers literature on retention and relationship-building that leads to the pathway development of enrolled students, with the hope that they may become lifelong learners. Although the field of AA continues to grow, we refer to scholarship which has shed invaluable light on the usefulness of retention programmes and individual student experiences using the longitudinal work of Kuh et al. (2005) and Tinto (1993; 1999).

As regards support for students, Kuh et al. (2005) view advising as a way students can connect to campus and help them feel someone cares for their academic growth and well-being by looking out for them. This validates the commitment of an institution to its students, which is confirmed by Tinto $(1999 ; 2014)$ as essential for the retention of students until graduation.

This is further supported by Tinto's theory of attrition. Once given access to education, support is needed to reap developmental success of the student (Tinto 2014). Sorensen and Donovan (2017) add that retaining students is not limited to factors associated with performance. As previously mentioned, student support should not only include academic support (intellectual and academic challenges, such as speaking up in class, communicating with lecturers; developing semester module schedules; balancing academic and social life and study-related challenges, such as how to study, time-management issues and goal setting) but also social support and development (personal and interpersonal challenges, such as moving to a new environment, leaving family, living with a roommate, meeting new people and identity issues, making personal decisions every day; facing new peer pressures, such as sex, drugs, alcohol, et cetera; managing conflict situations and physical challenges, such as forming positive health habits and breaking problem habits, becoming self-reliant in managing health/stress; finding lifetime hobbies and activities) (Materechera 2018).

The Sustainability Tracking, Assessment and Rating System (STARS) is an example survey used in learning academic-related needs of students, and this also guides advisers during their "intentional" advising. From 2018 to 2019, the case institution employed the STARS survey. ${ }^{3}$ For the case university, students indicated their needs regarding academic skills development, which were directly associated with the work of student academic advisers, as follows:

Table 1: Skills development needs in the case institution based on STARS ${ }^{\circledR} 2019$ 


\begin{tabular}{|l|c|}
\hline Student needs & Total number of students \\
\hline Exam-writing skills & 2652 \\
\hline Test-taking skills & 1484 \\
\hline Time-management skills & 1720 \\
\hline Study skills & 1490 \\
\hline
\end{tabular}

However, other indicators are measured on student needs such as computer, writing, reading, mathematical skills development, motivation, integration, wellbeing, and finances. These indicators suggest that student support and development initiatives should be in pursuit of the overall development of the student. Academic advising at the case institution will be informed by the Beginning University Survey of Student Engagement (BUSSE) 4 survey as from 2020.

The retention goals of an institution (for example, a university) are a joint and “intentional" effort by various stakeholders whose decisions are usually based on planning and strategy to shape the educational experience of all students (Kimball and Campbell 2013; North 2018; Schreiber et al. 2014). Student experiences differ across institutions, as they attract different kinds of staff and students coupled with resource availability. Tinto (1999) posited five institutional conditions that would lead to student success and development during students' stay at the university:

- when an institution sets high expectations that are clear and consistent, students are more likely to be persistent and succeed to graduation;

- $\quad$ availability of support to students;

- $\quad$ reliable and fast feedback to students on academic performance;

- $\quad$ opportunities for involvement with peers, faculty members and staff; and

- learning is relevant and constitutes value added.

Relating these conditions to AA, Tinto $(1999,2)$ noted:

"Students do best in settings where expectations are clear and consistent. This is particularly evident in the domain of academic advising. Students needs to be clear about what is expected of them and what is required for successful completion of both courses and programs of study. Students, especially the many who are undecided about their plans, needs to understand the road plan to completion and know how to use it to achieve personal goals."

Massification of education has brought about increased access to higher education, especially to disadvantaged students living in rural settlement. It is important that all educational policies at the national and institutional level can enhance access to diverse students, and institutions must put structures in place (such as AA, amongst others) to cater for training and developing pathways for these students' progression during their time at the institution and possibly beyond. 
The data presented in the article reflect on some of these ideals.

\section{METHODOLOGY}

The purpose of the study was to reveal how one-on-one AA influences progressive and developmental pathways geared towards students' retention and impacts students' academic performance. The short-term impact of one-on-one AA on students' academic performance was measured by means of a systematic quantitative investigation so as to establish whether improved student academic performance had been achieved. This research was conducted at one campus of a university in South Africa with the main business of teaching and learning, research, and community engagement.

Action research was chosen as a research design tool to (a) explore and bridge the gap between AA procedures (theory) and student academic performance and achievement (practice) (O’Connor 2016; Somekh 1995); (b) change the status quo (if necessary) by finding practical interventions/solutions/alternatives (Maree 2013) that may ultimately contribute to enhancing/transforming student academic performance and achievement; and (c) for future study, to evaluate and assess the effectiveness of the interventions/solutions/alternatives (Maree 2013).

Data obtained for this study are based on one-on-one consultations for AA for the academic years 2018 and 2019. Two sets of samples were used to provide descriptive and explanatory analysis on records of the two consecutive academic years and the short-term impact on students' academic performance. Pre- and post-academic results were compared to determine the change after consultation. Data were collected by means of a standardised student-support record completed by students at the onset of the first consultation with the student academic adviser. Table 2 provides the methodological framework for this study and indicates the alignment of the sample design, aim and objectives, variables and analytic method associated with the empirical aspects of the study.

Table 2: Methodological framework for the study

\begin{tabular}{|c|c|c|c|c|}
\hline Aim & Objectives & Sample design & $\begin{array}{c}\text { Independent } \\
\text { variables }\end{array}$ & $\begin{array}{l}\text { Analytic } \\
\text { method }\end{array}$ \\
\hline $\begin{array}{l}\text { Determine the } \\
\text { influence of } \\
\text { academic } \\
\text { advising on } \\
\text { academic } \\
\text { performance } \\
\text { using pre- and } \\
\text { post-examination } \\
\text { results after }\end{array}$ & $\begin{array}{l}\text { Report on data } \\
\text { collected through } \\
\text { one-on-one } \\
\text { student academic } \\
\text { advising } \\
\text { consultations on } \\
\text { records of two } \\
\text { consecutive } \\
\text { academic years. }\end{array}$ & $\begin{array}{l}\mathrm{N}=161 \\
\text { Includes all students who } \\
\text { had one-on-one } \\
\text { consultations for semesters } \\
1 \text { and } 2 \text { of } 2018 \text { and } 2019 . \\
\text { Self-selection for entire } \\
\text { census sampling for } \\
\text { consultations are used. }\end{array}$ & \multirow[t]{2}{*}{$\begin{array}{l}\text { Consultations } \\
\text { Study level } \\
\text { Referral entities } \\
\text { Student needs } \\
\text { These variables } \\
\text { are associated } \\
\text { with AA to the } \\
\text { dependent } \\
\text { variable academic } \\
\text { performance. }\end{array}$} & $\begin{array}{l}\text { Descriptive and } \\
\text { explanatory } \\
\text { analysis }\end{array}$ \\
\hline $\begin{array}{l}\text { exposure to one- } \\
\text { on-one } \\
\text { consultation on a } \\
\text { short-term basis. }\end{array}$ & $\begin{array}{l}\text { Measure short- } \\
\text { term impact of } \\
\text { one-on-one } \\
\text { student academic }\end{array}$ & $\begin{array}{l}\mathrm{n}=91 \\
\text { Only student consultations } \\
\text { for semester } 2 \text { of } 2018 \text { and } \\
2019 \text { across study levels. }\end{array}$ & & $\begin{array}{l}\text { Positive and } \\
\text { negative counts } \\
\text { of academic } \\
\text { performance }\end{array}$ \\
\hline
\end{tabular}




\begin{tabular}{|l|l|l|l|l|}
\hline Aim & \multicolumn{1}{|c|}{ Objectives } & \multicolumn{1}{|c|}{ Sample design } & \multicolumn{1}{|c|}{$\begin{array}{c}\text { Independent } \\
\text { variables }\end{array}$} & \multicolumn{1}{c|}{$\begin{array}{c}\text { Analytic } \\
\text { method }\end{array}$} \\
\hline & $\begin{array}{l}\text { advising on } \\
\text { students' } \\
\text { academic } \\
\text { performance. }\end{array}$ & $\begin{array}{l}\text { Semester 1 was used as } \\
\text { baseline in order to measure } \\
\text { impact against semester } 2 \\
\text { academic results for 2018 } \\
\text { and 2019. }\end{array}$ & & $\begin{array}{l}\text { before and after } \\
\text { consultations in } \\
\text { simple } \\
\text { frequencies and } \\
\text { percentages } \\
\end{array}$ \\
& & $\begin{array}{l}\text { Self-selection and } \\
\text { judgemental sampling were } \\
\text { used. }\end{array}$ & & analysis were \\
& & & used. \\
\hline
\end{tabular}

The student administrative system was consulted in order to include the participation, examination and module marks of the students in the semester preceding the consultation. The pre- and post-results helped in determining the short-term impact of AA. Demographical information, such as gender, race and faculty, were held confidential,

\section{FINDINGS AND DISCUSSION}

In this section, the data are presented in graphs and tables using descriptive statistics. The findings are presented under two subheadings.

\section{Descriptive analysis of one-on-one student academic advising consultations}

The number of consultations were not limited, and students were encouraged to do follow-up consultations as needed. The number of consultations varied between one (single consultation) to a maximum of five (multiple follow-up consultations). Most consultations were either a single visit (43\%) or two visits (49\%) (see Figure 2). Perhaps these students' needs were met after the second consultation, or referral to other professional structures was adequate and effective.

In Figure 3, the study level of the students varied for first-, second-, third-, fourth-year and honours students. First-year students were in the top tier with the most consultations (56\%), and a noticeable decline was observed in consultations from second-year to honours-level students. Typically, first-year students were not as knowledgeable as the other cohorts about the academic and social construct and context of the institution.

To indicate the complexity of the student development pathway, a breakdown of the referring entity is important to understand the various role players who are involved in the process as well as the potential influence they can have on the outcome which is linked to academic achievement of students. These referring entities are from peer-assisted programmes from CTL and other professional directorates. However, the highest number of referrals was self-referrals (31\%), which are students who consulted with the student academic adviser of their own accord. 


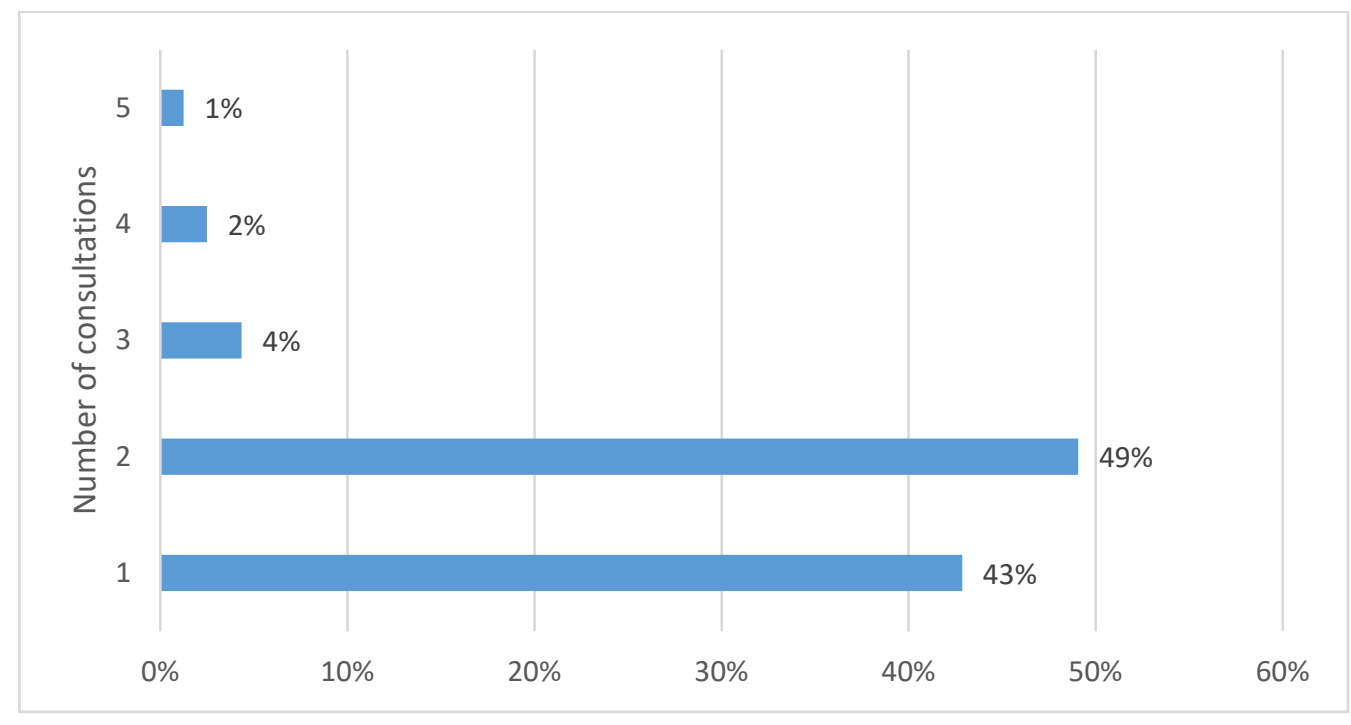

Figure 2: Total number of consultations from 2018 to 2019

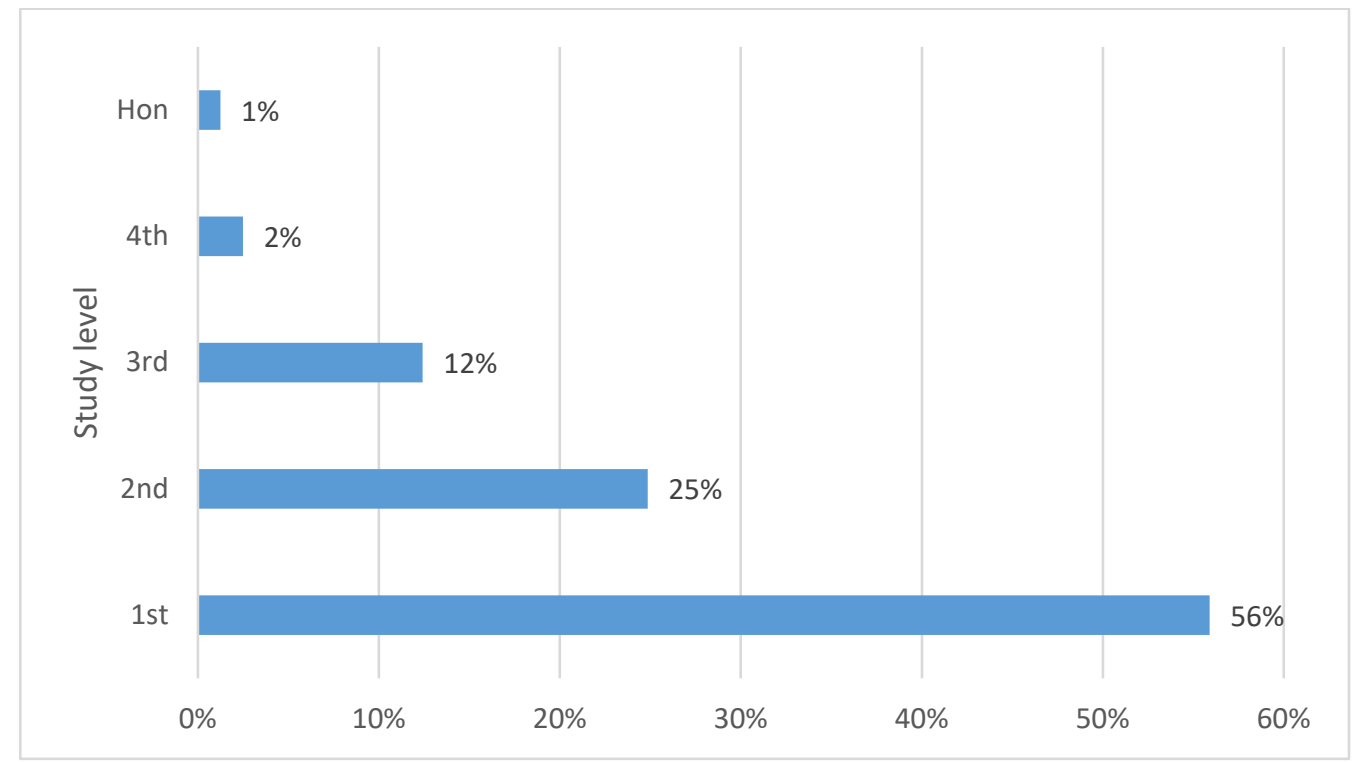

Figure 3: Consultations per study level

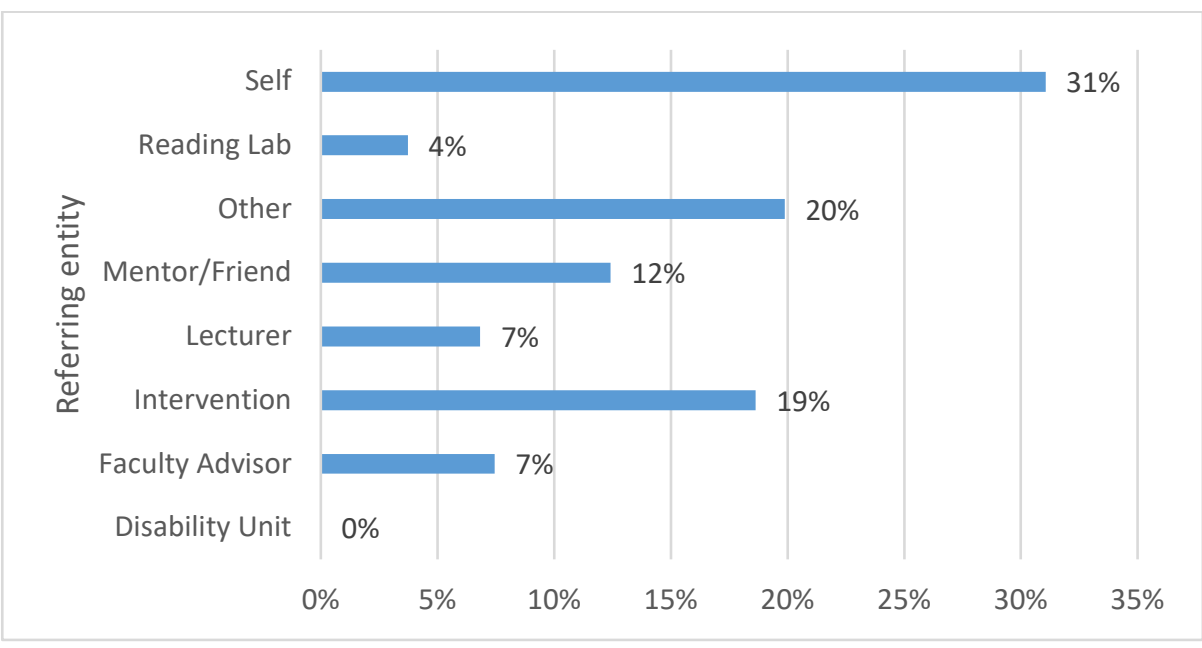

Figure 4: Referring entities 
Figure 5 presents the data related to causes for support which led to advising. The needs outlined in Figure 5 were established by the indicators from the STARS survey. Looking at student needs (which are typical reasons why students needed to consult with the student academic adviser), two areas of alarming and obvious needs are: the need to develop time management skills (35\%) and study methods (34\%) for higher education learning.

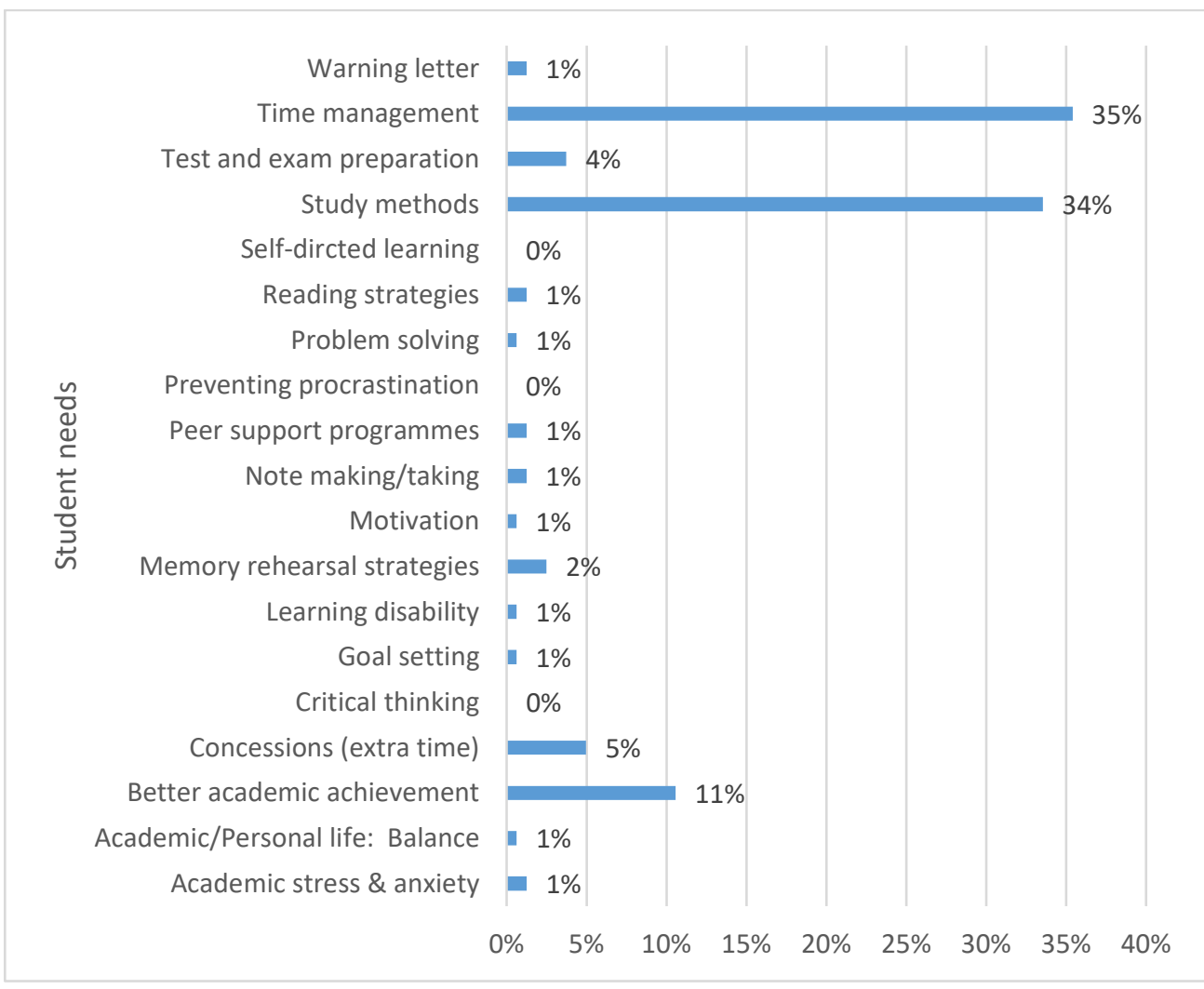

Figure 5: Student needs

\section{Descriptive analysis of the short-term impact of academic advising on students' academic performance}

To measure the short-term impact of one-on-one AA consultations on student academic achievement, only student consultations for the second semester of 2018 and 2019 across study levels were used $(n=91)$. This allowed for the use of the results of the end of the first semester (i.e., the academic results of students prior to consulting with the student academic adviser) as a baseline in order to measure impact against second-semester academic results for 2018 and 2019 (i.e., the academic results of students after consulting with the student academic adviser in the second semester). This allowed for a comparison to be made. The academic results used for this comparison are the mean scores of the participation results during the semester and the examination results at the end of the semester. 
Four independent variables (total number of second-semester consultations from 2018 and 2019; second-semester consultations per study level; referral entities; and student needs) associated with AA were reviewed to establish the impact on the dependent variable - in this case, the academic performance of students.

The number of consultations was not limited; so, there were opportunities to do follow-up consultations. There were also more single and twice visits (see Table 3); however, students who had up to three visits (consultations) had the highest academic gain (9\%), with all the students improving. This is also the case with students who consulted five times. However, only about 50 per cent of students who consulted once and twice had academic gains of 8 per cent and 6 per cent respectively.

Table 3: Total number of second-semester consultations from 2018 to 2019

\begin{tabular}{|c|c|c|c|c|c|c|c|c|}
\hline $\begin{array}{c}\text { Number of } \\
\text { consultations }\end{array}$ & Total & $\begin{array}{c}\text { Ave \% } \\
\text { Change }\end{array}$ & $\begin{array}{c}\text { Pos } \\
\text { Count }\end{array}$ & Pos \% & $\begin{array}{c}\% \\
\text { Increase }\end{array}$ & $\begin{array}{c}\text { Neg } \\
\text { Count }\end{array}$ & Neg \% & $\begin{array}{c}\% \\
\text { Decrease }\end{array}$ \\
\hline 1 & 49 & 1 & 24 & 49 & 8 & 25 & 51 & -6 \\
\hline 2 & 32 & 1 & 18 & 56 & 6 & 14 & 44 & -5 \\
\hline 3 & 4 & 9 & 4 & 100 & 9 & 0 & 0 & 0 \\
\hline 4 & 4 & -4 & 1 & 25 & 3 & 3 & 75 & -6 \\
\hline 5 & 2 & 2 & 2 & 100 & 2 & 0 & 0 & 0 \\
\hline
\end{tabular}

Table 4 indicates that the study level of the students who consulted with the student academic adviser during the second semester was also high. First-year students had an average module percentage increase of 1.9 per cent. On average, percentages increased per study level. An academic increase of 3.0 per cent was also observed for third-year students. This may be attributed to motivation for graduation, as this is students' exit level.

Table 4: Second-semester consultations per study level

\begin{tabular}{|l|c|c|c|c|c|c|c|c|}
\hline Study level & Total & Ave \% Change & Pos. Count & Pos. \% & \% Increase & Neg. Count & Neg. \% & \% Decrease \\
\hline 1st & 44 & 1.9 & 27 & 61 & 6.8 & 17 & 39 & -6.1 \\
\hline 2nd & 28 & -0.6 & 13 & 46 & 5.2 & 15 & 54 & -5.7 \\
\hline 3rd & 11 & 3.0 & 6 & 55 & 10.8 & 5 & 45 & -6.4 \\
\hline 4th \& Hon & 4 & 1.0 & 2 & 50 & 6.8 & 2 & 50 & -4.8 \\
\hline
\end{tabular}

The data related to the breakdown of the referring entity (see Table 5) indicate that the highest number of students $(42 \%)$ who of their own accord registered for consultation had an average change of 1.2 per cent in their academic record. The highest average percentage increase of 9.5 per cent in academic achievement was, however, observed among the students that were referred by faculty advisors for AA. Students may be exposed to more information when they experience more than one advisor. 
Table 5: Referring entities

\begin{tabular}{|l|c|c|c|c|c|c|c|c|}
\hline Referring entity & Total & Ave \% Change & Pos Count & Pos \% & \% Increase & Neg Count & Neg \% & \% Decrease \\
\hline Disability Unit & 0 & 0.0 & 0 & 0 & 0 & 0 & 0 & 0 \\
\hline Faculty Advisor & 6 & 9.5 & 5 & 83 & 12 & 1 & 17 & -4 \\
\hline Intervention & 23 & 1.1 & 13 & 57 & 6 & 10 & 43 & -6 \\
\hline Lecturer & 4 & -1.1 & 1 & 25 & 3 & 3 & 75 & -3 \\
\hline Mentor/Friend & 9 & -2.0 & 4 & 44 & 4 & 5 & 56 & -7 \\
\hline Other & 10 & -0.7 & 5 & 50 & 5 & 5 & 50 & -6 \\
\hline Reading Lab & 1 & 4.5 & 1 & 100 & 5 & & 0 & 0 \\
\hline Self & 38 & 1.2 & 20 & 53 & 7 & 18 & 47 & -6 \\
\hline
\end{tabular}

The reasons for consulting student academic advisers varied but centred mostly on better academic achievement and developing study methods and time-management skills. However, students whose need was academic achievement on average showed no improvement between the two recorded semesters, but students who consulted for better time management improved 4 per cent on average.

One student who opted for AA because of academic stress and anxiety showed a module percentage increase of 14 per cent (Table 6). In addition, students that received warning letters from faculty regarding academic achievement and those that needed help in setting academicand life goals also improved academically.

Table 6: Student needs

\begin{tabular}{|l|c|c|c|c|c|c|c|c|}
\hline \multicolumn{1}{|c|}{ Student needs } & Total & $\begin{array}{c}\text { Ave } \% \\
\text { Change }\end{array}$ & $\begin{array}{c}\text { Pos } \\
\text { Count }\end{array}$ & Pos \% & $\begin{array}{c}\text { \% } \\
\text { Increase }\end{array}$ & $\begin{array}{c}\text { Neg } \\
\text { Count }\end{array}$ & Neg \% & $\begin{array}{c}\% \\
\text { Decrease }\end{array}$ \\
\hline $\begin{array}{l}\text { Academic stress \& } \\
\text { anxiety }\end{array}$ & 1 & 14 & 1 & 100 & 14 & 0 & 0 & \\
\hline $\begin{array}{l}\text { Academic/personal } \\
\text { life: balance }\end{array}$ & 1 & -4 & 0 & 0 & & 1 & 100 & -4 \\
\hline $\begin{array}{l}\text { Better academic } \\
\text { achievement }\end{array}$ & 13 & 0 & 8 & 62 & 3 & 5 & 38 & -6 \\
\hline $\begin{array}{l}\text { Concessions (extra } \\
\text { time) }\end{array}$ & 6 & 3 & 4 & 67 & 6 & 2 & 33 & -4 \\
\hline Goal setting & 1 & 9 & 1 & 100 & 9 & 0 & 0 & \\
\hline Learning disability & 1 & -1 & 0 & 0 & & 1 & 100 & -1 \\
\hline $\begin{array}{l}\text { Memory rehearsal } \\
\text { strategies }\end{array}$ & 4 & -5 & 1 & 33 & 4 & 2 & 67 & -5 \\
\hline Note making/taking & 2 & 0 & 1 & 50 & 5 & 1 & 50 & -5 \\
\hline $\begin{array}{l}\text { Peer support } \\
\text { programmes }\end{array}$ & 1 & 4 & 1 & 100 & 4 & 0 & 0 & -1 \\
\hline Problem-solving & 1 & -1 & 0 & 0 & & 1 & 100 & -9 \\
\hline Reading strategies & 1 & -9 & 0 & 0 & & 1 & 100 & -7 \\
\hline Study methods & 29 & 0 & 13 & 45 & 8 & 16 & 55 & -7 \\
\hline $\begin{array}{l}\text { Test- and exam } \\
\text { preparation }\end{array}$ & 5 & -1 & 1 & 20 & 11 & 4 & 80 & -4 \\
\hline Time management & 23 & 4 & 16 & 70 & 8 & 7 & 30 & -6 \\
\hline Warning letter & 2 & 6 & 2 & 100 & 6 & 0 & 0 & \\
\hline
\end{tabular}




\section{CONCLUSION AND RECOMMENDATIONS}

It is evident that first-year students sought academic development and support the most. This may result from an extensive first-year experience programme and effort to introduce AA to students during the campus reception and orientation programme at the onset of every academic year.

First-time students' first semester at university is a transitional period in which they form expectations with regard to the higher education learning environment (Wojciechowski and Palmer 2005). During this transitional period from secondary to tertiary education, first-time students need to develop a basic or core knowledge framework, essential communication, presentation and effective group collaboration skills, analytical thought patterns and problemsolving techniques, effective time-management and goal-setting skills, the ability to selfmotivate and persevere (grit, resilience, growth mindset), self-directed learning of new content, gain familiarity with navigating the university's LMS, an understanding of the complexities of assessment rubrics and ethical research skills, and develop computer, reading and academic writing skills (University of Sydney 2015, 16; Wojciechowski and Palmer 2005). This is also supported by Materechera (2018).

The data support the need to develop the above-mentioned skills for higher education learning. This study highlighted time-management skills, study methods, better academic achievement and test and exam preparation as the highest-ranking reasons why students consult an academic adviser. However, this was pre-empted by the STARS survey that was completed by first-year students at the case institution, which also indicated exam-writing skills, testtaking skills, time-management skills and study skills as top students' academic skills development needs.

Although a noticeable decline was observed in consultations once students were done with their first year of study, there was an average percentage increase of 3.0 per cent observed for third-year students' post-consultation. In terms of the National Qualifications Framework (NQF), students exit at level 7 (CHE 2013b). The third-year students may have developed intrinsic motivation to progress to graduation; therefore, besides consultations with advisers, other confounding variables may have also contributed to their improvement.

This article is positioned to reveal the short-term impact of AA on academic performance. Theories on student retention, for example, Tinto (1999) postulates that the provision of support for students like that of AA is just one of the institutional conditions or requirements for student success and development during their time at the university. The short-term data qualifies this position that not all students who consulted profited. Evidence is seen in the comparative 
observations in data between the distribution of students who benefited and those who did not showed that just over half of participating students per consultation had academic gains. Students who did not profit could be in need of other kinds of support in addition to AA. This suggests that the "intentional" process should include due consideration and knowledge of the support structures within the institution and the investigating of influencing factors on the academic progression of these students. This would allow for effective use of the institutions' resources and referral which would allow for a proper tracing system to be in place to track student progress.

The study showed that the highest percentage increase of 23.5 per cent was achieved by a first-year student, referred by a faculty adviser, who consulted with the student academic adviser to develop study methods for higher education. Looking at the other end of the spectrum, the study also showed that a student who showed the highest percentage decrease of -22.7 per cent was referred to the student academic adviser by Student Counselling (as an intervention) to develop study methods for higher education. These findings concur with the premise of the article that, after students are admitted to an institution, their motivational level, choices, association, behaviours, orientation, et cetera, determine their success within their institutions of learning (Kimball and Campbell 2013; Pascarella and Terenzini 2005; Tinto 2014, 6). In other words, if one-on-one student AA leads to improved performance, then retention is achieved if all other retention influencers remain present and constant. The participating students who did not improve could have been affected by other indicators/variables which is out of the study scope. An example of such importance of AA in the case institution is already referred to in the literature. After the proper support (which was social and psychological) was put in place for the student, she excelled academically.

Knowledge creation during pro-active action research is continuous and takes place in a cyclical, iterative process. Therefore, this study should be repeated annually to build up an enlarged dataset. An enlarged and more comprehensive dataset (including across-campus data of all one-on-one AA consultations) and pooling the experience from student academic advisers across campuses would allow for a better understanding of the phenomenon of interest (McMillan and Schumacher 2014). This research only focused on academic-related outcomes, but the findings reiterate that the retention goals of an institution should be a joint and "intentional" effort by various stakeholders. Transparent self-reporting frameworks, such as STARS and/or BUSSE, which measure first-year students' pre-university experiences and participation in educationally purposeful activities, provide institutions the opportunity to align all their support and development efforts with students' expectations. Various stakeholders are 
involved in students' developmental pathways to academic success. A collaborative effort between all student support and development services and resources, rather than fragmented efforts by stakeholders, may contribute more effectively to the social wellbeing of students and is paramount to academic success.

Massification of education, which brought about increased access to higher education, should not deter institutional efforts to put structures in place to cater for training and developing pathways for students' progression during their time at their institution. If this study is to be undertaken over multiple years (for the duration of the students' study) as part of a multifaceted and collaborative approach by student support and development services and resources, potential dropouts can be identified timeously for intervention and a progressive pathway leading to academic success can be better ensured.

\section{NOTES}

1. Academic advising (AA) takes place in "situations in which an institutional representative gives insight or direction to a college student about an academic, social, or personal matter. The nature of this direction might be to inform, suggest, counsel, discipline, coach, mentor, or even teach" (Kuhn 2008, 3).

2. The "intentional" process of AA in context means what informs the patterns and ways of how academic advisers support students' lifelong development within an academic institution of learning, with a focus on one-on-one AA which critically depicts the outcome of the achievement seen when students pass satisfactorily in subjects and also contributes to the success of the school/department/faculty to which they have been registered when students and professional staff (in this case, an academic adviser) work collaboratively. Furthermore, for the purpose of this article, the "intentional" process is shaped powerfully by the values, beliefs and assumptions guiding professional staff members when advising students, as emphasised by scholarship (Bensimon 2007; Bloland, Stamatakos, and Rogers 1994).

3. The Sustainability Tracking Assessment and Rating System ${ }^{\text {TM }}$ (SRARS) survey is a transparent, self-reporting framework for universities to measure their sustainable performance to test students' readiness to benefit from university education.

4. BUSSE measures entering "first-year students' pre-university experiences and their expectations regarding participation in educationally purposeful activities" (University of the Free State 2020).

\section{REFERENCES}

Benedicks, R. 2018. "Learning ecosystems: What are they, and what can they do for you?" Training Industry. $\quad$ https://trainingindustry.com/articles/strategy-alignment-and-planning/learningecosystems-what-are-they-and-what-can-they-do-for-you/ (Accessed 15 December 2018).

Bensimon, E. M. 2007. "The underestimated significance of practitioner knowledge in the scholarship of student success." The Review of Higher Education 30(4): 441-469.

Bloland, P. A., L. C. Stamatakos, and R. R. Rogers. 1994. Reforms in student's affairs: A critique of student's development. Greensboro: University of North Carolina Press.

CHE see Council on Higher Education. 
Council on Higher Education. 2013a. A proposal for undergraduate curriculum reform in South Africa. Pretoria, CHE.

Council of Higher Education. 2013b. "National Qualification Act, 2008 (Act No 67 of 2008): Higher Education Qualifications Sub-Framework." (Notice 891). Government Gazette, 36803: 89130 August.

Department of Higher Education and Training. 2017. 2000 to 2014 first time entering undergraduate cohort studies for public higher education institutions. Pretoria: Department of Higher Education and Training.

DHET see Department of Higher Education and Training.

Drake, J. K. 2011. "The role of academic advising in student retention and persistence." About Campus: Enriching the Student Learning Experience 16(3): 8-12.

Evans, N. J., D. S. Forney, F. M. Guido-DiBrito, L. D. Patton, and L. A. Renn. 2010. Student development in college: Theory, research and practice. $2^{\text {nd }}$ Edition. San Francisco, CA, Jossey Bass.

Harper, S. R. and S. J. Quaye. Ed. 2009. Students engagement in Higher Education: Theoretical perspectives and practical approaches for diverse populations. New York, Routledge.

Hutson, B. L., J. L. Bloom, and Y. He. 2009. "Reflection in advising." Academic Advising Today 32(4): 12.

Jaccard, J. and J. Jacorby. 2010. Theory constructing and model-building skills: A practical guide for social scientists. New York, Guilford.

Kimball, E. and S. M. Campbell. 2013. "Advising Strategies to Support Learning Success: Linking Theories and Philosophy with Intentional Practice.” In Academic Advising Approaches: Strategies that Teach Students to Make the Most of College, ed. J. K. Drake, P. Jordan, and M. A. Miller, 315. San Francisco: Jossey-Bass.

Kuh, G. G., J. Kinzie, J. H. Schuh, and E. J. Whitee. Ed. 2005. Student success in college: Creating conditions that matter. San Francisco, CA, Jossey Bass.

Kuhn, T. 2008. "Historical Foundations of Academic Advising." In Academic Advising: A Comprehensive Campus Process, ed. Gordon, Habley and Grites. San Francisco, Jossey-Bass.

Levin, B. B. and Y. He. 2008. "Investigating the content and sources of preservice teachers' personnel practical theories (PPTs)." Journal of Teacher Education 59(1): 55-68.

Maree, K. Ed. 2013. First steps in research. Pretoria: Van Schaik.

McMillan, J. and S. Schumacher. 2014. Research in education. Edinburgh, Pearson Education Limited.

Materechera, E. 2018. "Peer mentoring guide." NWU. Unpublished document.

O'Connor, M. 2016. "Data-based instructional decision making related to basic early literacy skills in the Intermediate Phase." Theses: North-West University.

Pascarella, E. T. and P. T. Terenzini. 2005. How college affects students: A third decade of research, Vol. 2. San Francisco, CA, Jossey-Bass.

Schreiber, B., T. Luescher-Mamashela, and T. Moja. 2014. "Tinto in South Africa: student integration, persistence and success, and the role of student affairs." Journal of Student Affairs in Africa 2(2): $\mathrm{V}-\mathrm{X}$.

Somekh, B. 1995. "The contribution of action research to development in social endeavours: A position paper on action research methodology." British Educational Research Journal 21(3): 339-355.

Sorensen, C. and J. Donovan. 2017. "An examination of factors that impact the retention of online students at a for-profit university." Online Learning 21(3): 206-221. https://eric.ed.gov/?id= EJ1154164.

Strange, C. C. and L. H. Banning. 2001. Educating by design. San Francisco, CA, Jossey Bass.

Tinto, V. 1993. Leaving college: Rethinking the causes and cures of student attrition. San Francisco, 


\section{CA, Jossey Bass.}

Tinto, V. 1999. "Taking retention seriously: Rethinking the first year of college." NACADA Journal 19(2): 5-9.

Tinto, V. 2014. "Reflective Practice: Tinto's South African lectures." Journal of Student Affairs in Africa 2(2): 5-28.

University of the Free State. 2020. "Surveys of student engagement (BUSSE)." https://www.ufs.ac.za/ sasse/busse-home/about-busse.

University of Sydney. 2015. "Building a culture of educational excellence." https://intranet.sydney.edu.au/content/dam/intranet/documents/news-initiatives/strategy/ Strategy-Discussion-Paper-Education-2.pdf. (Accessed 2 May 2020).

Wojciechowski, A. and L. B. Palmer. 2005. "Individual student characteristics: Can any be predicators of success in online classes.” Journal of Distance Learning Administration VIII(2): 1-20. 